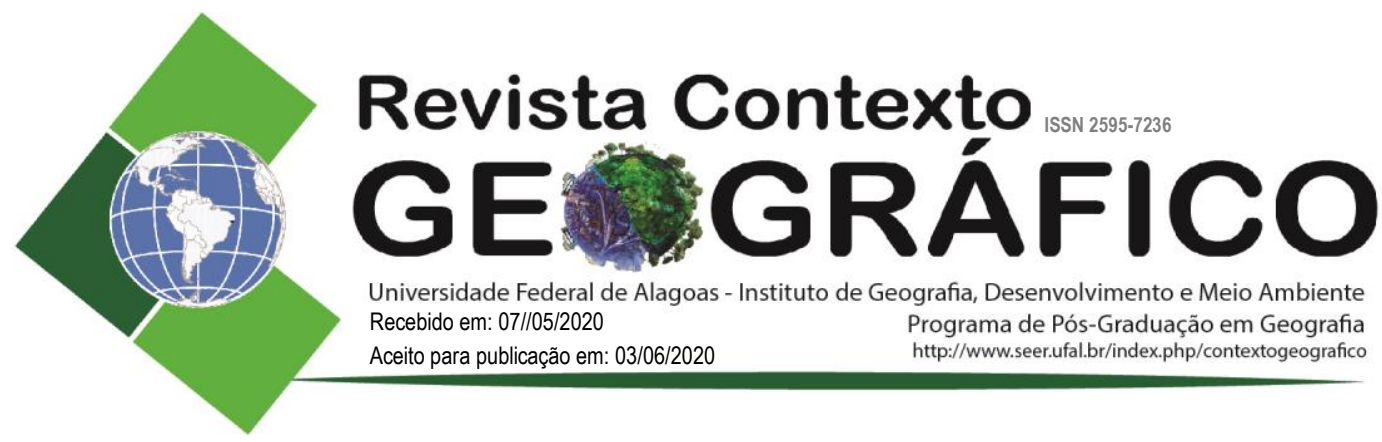

\title{
GLOBALIZAÇÃO E COVID19: GUERRA CONTRA UM INIMIGO INVISÍVEL
}

\author{
Paul Clívilan Santos Firmino \\ Doutorando do Programa de Pós-graduação em Geografia Humana do Departamento de \\ Geografia da Universidade de São Paulo, Brasil. \\ pcfirmino@usp.br
}

\begin{abstract}
RESUMO - O presente trabalho tem como objetivo analisar a expansão do COVID-19 mediante um viés geográfico, tendo como suporte nesta análise o avanço e intensificação do meio técnico-científico-informacional e o processo de globalização. Assim, alguns autores foram essenciais para pensar a realidade do mundo presente e como enfrentar essa guerra contra um inimigo invisível a olho nu: Bauman (1999), Castilho (2020), Mamigonian (1982), Santos ([1996] 2008), Schiffer (1996) entre outros que deram base teórica para a escrita destas laudas que seguem. Juntamente com essas referências foram feitas consultas em sites que tratam do COVID-19 e seus dados. Para tanto, a discussão envolve o papel e a importância do Estado no enfrentamento desta pandemia, apontando os principais direcionamentos que estão sendo tomados por diversos países, de acordo com as recomendações dos órgãos de saúde e sanitários responsáveis, como forma de minimizar e/ou evitar os danos causados pelo vírus, muitos deles irreversíveis, principalmente naqueles países que estão na periferia do sistema capitalista. No caso brasileiro, a partir de uma breve análise das desigualdades regionais existentes, mostrar-seá como está se dando o avanço do vírus por entre os estados e regiões.
\end{abstract}

Palavras-chave: Avanços Técnicos-Científicos-Informacionais; Globalização e Covid-19; Mundo e Brasil.

\section{GLOBALIZATION AND COVID 19: WAR AGAINST AN INVISIBLE ENEMY}

\begin{abstract}
The present study aims to analyze the expansion of COVID-19 through a geographical bias, having as support in this analysis the advance and intensification of the technical-scientific-informational environment and the globalization process. Thus, some authors were essential to think about the reality of the current world and how to face this war against an enemy invisible to the naked eye: Bauman (1999), Castilho (2020), Mamigonian (1982), Santos ([1996] 2008), Schiffer (1996), among others whom gave a theoretical basis for the writing of these pages that follow. Along with these references, queries were made on sites dealing with COVID-19 and its data. For this porpose, the discussion involves the role and importance of the State in facing this pandemic, pointing out the main directions are being taken by several countries, in accordance with the recommendations of the responsible health and sanitary agencies, in a manner such that to minimize and /or avoid the damage caused by the virus, many of them irreversible, especially in those countries that are on the periphery of the capitalist system. In the Brazilian case, from a brief analysis of the existing regional inequalities, it will be shown how the virus is spreading among the states and regions.
\end{abstract}

Keywords: Technical-Scientific-Informational Advances; Globalization and Covid-19; World and Brazil.

\section{INTRODUÇÃO}

A forte interação entre técnica, ciência e informação, marca profundamente o mundo do presente. Essa interação serviu de base para a constituição do meio técnico-científico-

$\begin{array}{llllll}\text { Revista Contexto Geográfico } & \text { MAceló-AL } & \text { V.5. N.9 } & \text { JULHO/2020 } & \text { P. } 01-15 & \text { PÁGINA } 1\end{array}$


informacional e, consequentemente, do atual processo de globalização (SANTOS, [1994] 2008). Seu marco data do fim da Segunda Guerra Mundial na década de 1940, acontecimento que afetou e desestruturou diversas nações, marcando um período histórico na humanidade que será sempre lembrado pela brutal violência e pelas consequências deixadas.

Nas décadas seguintes, os países foram se reconstruindo e investindo em arsenal de guerra, tendo como base, ciência e tecnologias cada vez mais de ponta, fortalecendo a economia e o mercado mundial que, por sua vez, ia se globalizando mediante as imposições das novas potencias mundiais, tendo à frente a potência norte-americana, os Estados Unidos, com uma acumulação material e incessante busca pelo lucro. Outros países, principalmente os mais devastados pela Guerra, passaram a direcionar investimentos para reconstrução não só das suas infraestruturas, como também de apoio as inúmeras famílias que sofreram diretamente seus impactos, através de programas de ajuda aos cidadãos, criados pelos Estados e visando suprir às necessidades básicas voltadas ao bem-estar e ao desenvolvimento saudável da vida que estava por se refazer.

Assim, ao longo das décadas as diversas nações passaram por crises internas e externas, resultantes não apenas dos desdobramentos do pós Segunda Guerra e da tensão que pairava em virtude da Guerra Fria, mas também das guerras internas aos países, a exemplo das ditaduras militares, como no Brasil, Chile e Argentina, na América Latina, crises mundiais como a do Petróleo nos anos 1970, o liberalismo econômico dos anos 90, ou até mesmo a mais recentemente crise de 2008. Todos esses marcos fazem parte de uma história recente da realidade mundial que, ao mesmo tempo que enriquecia uma minoria, colocava um grande contingente populacional na linha de frente das desigualdades sociais. Com isto, a necessidade de condições mínimas de sobrevivência para enfrentar as adversidades posta por uma sociedade de consumo, do chamado mundo globalizado, se faz mais urgente, visto que, esse mundo impõem-se para a grande parte da humanidade, conforme Santos ([2000] 2008), como uma fábrica de perversidades, onde aumenta-se o desemprego e a pobreza, o salário torna-se mais irrisório frente às necessidades dos trabalhadores, doenças que tinham sido extintas voltam a aparecer, como o sarampo no Brasil, e outras surgem e se propagam numa escalada como nunca visto antes, a exemplo do coronavírus SARS-CoV-2, ou conhecido como COVID-19.

Desta forma, o presente artigo tem como objetivo analisar e discutir a expansão do COVID-19 mediante um viés geográfico, tendo como suporte o avanço e intensificação do meio técnicocientífico-informacional e o processo de globalização atual. Para tanto, uma discussão em torno destes dois conceitos, bem como de desigualdades regionais, Estado, atores hegemônicos, entre outros, baseando-se em autores como Bauman (1999), Castilho (2020), Mamigonian (1982), Santos ([1996] 2008), Santos e Silveira ([2001] 2010), Schiffer (1996), Souza (1996) etc., mostraram-se fundamentais nesta análise. Atrelado a estes autores vale apontar as informações obtidas em sites como o da Organização Mundial da Saúde (OMS), Johns Hopkins University \& Medicine e do Ministério da Saúde do Brasil.

Dividimos o artigo em três partes importantes para entendermos esse fenômeno através da Ciência Geográfica e dos seus conceitos e categorias, tão caros e relevantes nesse momento. A primeira parte diz respeito a uma discussão do meio técnico-científico-informacional e da globalização, buscando entender como a mesma foi criada, com que interesse e a quem serve, mostrando suas contradições em momentos de crises como esta que o mundo está passando. $\mathrm{O}$ segundo momento é direcionado a analisar a propagação do COVID-19 no mundo mediante o entendimento antecipado da ideia de globalização, dando ênfase na importância do Estado no controle do vírus através de medidas que, além de proteger a saúde da população possa manter uma segurança financeira a todos aqueles afetados direta ou indiretamente pela propagação do COVID-19. Por fim, uma terceira parte traz o debate para o Brasil, o qual é analisado mediante a constituição do seu território, a realidade existente hoje de grandes desigualdades regionais e 
os dados sobre a propagação do vírus nos estados e regiões brasileiras.

\section{MEIO-TÉCNICO-CIENTÍFICO-INFORMACIONAL E GLOBALIZAÇÃO - BREVES NOTAS}

No ano de 1945 o mundo saía de uma das maiores guerras já vistas e presenciadas pela humanidade, a Segunda Guerra Mundial - conflito militar que envolveu diversas nações mundiais, incluindo as maiores potências à época - que, destruiu economicamente diversos países, ceifou muitas vidas e consolidou os Estados Unidos da América - EUA como potência mundial, de tal modo que o período seguinte ao fim da Guerra, aponta Mamigonian (1982, p. 42), correspondeu "a um grande avanço tecnológico americano (energia atômica, computadores, aviões a jato, etc.). A necessidade de ampliação dos superlucros no pós-guerra conduziu os oligopólios à criação de um espaço econômico unificado no centro do sistema capitalista".

Do ponto de vista geopolítico o mundo passou a ser dividido de um lado pelos EUA, capitalista, e do outro a União das Repúblicas Socialistas Soviéticas (URSS), socialista, ambas vitoriosas ao fim da Segunda Guerra que, juntamente com o Reino Unido e vários outros formavam os países Aliados, contra os países do Eixo (principalmente, Alemanha, Itália e Japão). Entretanto, em virtude da busca pelo poder e hegemonia, mantiveram-se numa constante tensão Pós-Guerra até os anos de 1980 - a chamada Guerra Fria -, chegando ao fim no ano de 1989 com a queda do Muro de Berlim (que dividia a Alemanha em Oriental e Ocidental, de um lado socialista apoiada pela URSS, e do outro capitalista com o apoio dos EUA) em virtude de diversos fatores, levando a derrota soviética frente à vitória do capitalismo representado por sua maior potência, os EUA e seu liberalismo econômico.

Vivia-se um momento de reconstrução não só da arquitetura das materializações impostas ao território em um período histórico anterior - período técnico -, como também da organização mundial no que diz respeito à vida e relações econômicas e políticas. Aquele período técnico já não era mais suficiente para justificar a nova realidade que o mundo passava a vivenciar. Estava, portanto, entrando em um novo período na história que, tem sua afirmação nos anos de 1970 mediante a forte interação entre técnica, ciência e informação, envolvendo não somente os países do primeiro mundo, mas agora tratava-se de ter o terceiro mundo como sustentação e propagação do mesmo (SANTOS, [1996] 2008). Tem-se então investimentos cada vez mais pesados em ciência, técnica e informação, como forma de alavancar as nações mundiais e afirmar aquelas já consolidadas.

Iniciava-se aí um novo período que seria sustentado por uma ideologia internacional dominante e valorização de suas novíssimas técnicas, seja na vida social ou profissional, dos objetos ou conjuntos de objetos técnicos, científicos e informacionais, criados com um alto grau de intencionalidade e já direcionados a fins pré-estabelecidos. Em contrapartida tinha-se a negação das técnicas e capitais locais e nacionais, como se estes não fossem mais necessários a um mundo que se globalizava, tornando-se fiel escudeiro do sistema capitalista que dominava e avançava por quase todos os países. Tinha-se a formação de uma globalização perversa, detentora de uma ideologia criada para satisfazer às necessidades dos atores hegemônicos do mundo novo que estava em formação. Conforme Santos (1996), buscava-se uma redução da possibilidade de afirmação das formas de viver, cuja solidariedade é baseada na contiguidade, na vizinhança solidária, para alargar as solidariedades verticais através das normas e regras impostas pela democracia de mercado que se constituía.

Destarte, pode-se dizer que os últimos decênios do século XX foram marcados pela gênese, formação e consolidação de um período denominado por Santos ([1996] 2008), de meio técnicocientífico-informacional. É através deste meio que se pode pensar nas manifestações geográficas do mundo do presente. Este meio passa a dar suporte a um processo de criação e legitimação da globalização que, "como ideologia que se vende e se impõe aos povos oprimidos é basicamente o 
projeto econômico-político americano de liderar o ultra-imperialismo futuro" (MAMIGONIAN, 2004, p. 146).

Então, pensar as transformações do presente mediante as imposições da globalização, é pensar o território - como dimensão do espaço geográfico - e os seus usos, onde os espaços requalificados passam a atender, principalmente, aos interesses dos atores hegemônicos da economia e da política (SANTOS [1996] 2008). Logo, os avanços tecnológicos, assim como os científicos e informacionais, passaram a ser determinantes para a concorrência entre as empresas capitalistas, criando vários tipos de guerras entre os países e impondo constantes lutas e tensões entre os trabalhadores que passavam a se tornar um exército industrial de reserva (MARX, [1859] 2003), tendo como pressuposto básico saciar a sede por acumulação de capital e obter um melhor lugar no 'pódio' do mundo global. Assim, é evidente que "na ideologia econômica contemporânea o progresso técnico é 'deus ex-machina' e o aumento do rendimento é o objetivo dos modelos econômicos" (MAMIGONIAN, 1982, p. 39).

Diante disto, podemos dizer que esse meio técnico-científico-informacional é a cara geográfica do atual processo de globalização (SANTOS [1994] 2008) que, impõe a todas as pessoas um sentimento de igualdade, seja em relação ao poder de acesso aos meios de compras e informações, seja no que se refere aos sistemas de educação e saúde, por exemplo. Assim, pode-se pensar o período da globalização conforme apontado por Silveira (1999, p. 21), onde o mesmo é "caracterizado pela influência acelerada de fatores originários acima do Estado". É possível afirmar que as imposições se dão na maioria das vezes mediante saída do Estado em suas gestões e entrada voraz dos sistemas privados na organização e controle dos mesmos, levando através da informação, muitas vezes manipulada pela grande mídia, de que cada um pode e deve arcar com sua educação, saúde, segurança etc., tirando do Estado a responsabilidade e jogando nas mãos da população que, já arca com as mesmas, mediante os diversos tributos pagos.

É a alienação imposta pelo sistema capitalista representado pelas grandes empresas das grandes potências mundiais em parceria com os estados e difundida pelos mais diversos veículos de comunicação. São as normas, regras e ditames impostos pelo mercado mundial, abraçado e acolhido por diversos países comandados por uma elite política capitalista de direita e/ou extrema direita, como é o caso atual do Estado brasileiro, distanciando de metas de desenvolvimento interno e agravando as condições socioeconômicas da maioria da população (SCHIFFER, 1996). Constituindo assim, novas desigualdades e aprofundando aquelas já existentes, a exemplo da fome que, mesmo diante dos avanços técnicos e das modernizações presentes no mundo urbano e rural, acomete milhões de pessoas no mundo todo, como bem já apresentou Josué de Castro ([1951] 1968), junto com outras mazelas causadas pelas perversidades da globalização. Isto mostra, segundo Bauman (1999, p. 68) que:

A globalização não diz respeito ao que todos nós, ou pelo menos os mais talentosos e empreendedores, desejamos ou esperamos fazer. Diz respeito ao que está acontecendo a todos nós. Refere-se explicitamente às forças anônimas, estendendo-se para além do alcance da capacidade de desígnio e ação de quem que seja em particular.

Pensando desta forma, pode-se dizer que as últimas décadas do século XX e estas primeiras do século XXI levaram a uma mudança drástica nos modos de vida de grande parte da população mundial. $\mathrm{O}$ acesso aos mais diversos objetos tecnológicos, o acesso a todo tipo de informação (a maioria transmitida como verdades únicas) e a busca desenfreada pelo 'luxo' e consumo, abriram espaço ao mesmo tempo para alavancar e solidificar as grandes economias mundiais como destruir pequenas e médias economias. Tudo passou a girar em torno do dinheiro - uma invenção da vida de relações e aparece como decorrência de uma atividade econômica para cujo 
intercâmbio o simples escambo não basta (SANTOS, [2000], 2008) - e da mais-valia, uma acumulação sem precedentes. O dinheiro passou a ser protagonista, colocando para escanteio o ser humano e o essencial da vida, as relações sociais.

Essa é a verdadeira globalização, a globalização econômica, que leva ao fechamento de fronteiras dos países mais ricos e poderosos do mundo, a exemplo dos EUA; a quebra de leis e direitos trabalhistas conquistados a duras penas ao longo das décadas, como no Brasil com as medidas tomadas pelos governos de Michel Temer e Jair Messias Bolsonaro pós impeachment sofrido pela então eleita democraticamente Presidente Dilma Rousseff, evento ocorrido num alinhamento aos interesses neoliberais; ao aumento de trabalhadores(as) informais em virtude da retirada de seus direitos; ao aprofundamento das desigualdades e, consequentemente, da fome; a volta de doenças e ou chegada de outras novas; entre outros acontecimentos que atingem, principalmente, as classes mais pobres e desassistidas da sociedade.

\section{A URGÊNCIA DO ESTADO NO PERÍODO ATUAL FRENTE AO COVID-19}

O despontar do século XXI trouxe consigo a imposição de uma lógica que busca incessantemente, através dos seus representantes, o lucro fácil e acúmulo de riquezas. Uma imposição que visa extrair da classe trabalhadora o seu máximo, sem possibilitar a esta refletir sobre sua condição de seres pensantes e, enquanto trabalhadores, responsáveis por girar a 'roda' econômica que sustenta e dá vida a uma classe muito pequena do sistema capitalista, a dos ricos, que oprime e submete as demais classes a situações de dependências.

Paralelamente aos avanços e benefícios desse processo direcionados a um grupo específico, têm-se as crescentes disparidades entre países, regiões, estados e municípios, observadas por exemplo, pela impregnação cada vez mais crescente de objetos técnicos-científicosinformacionais em espaços intencionalmente selecionados, mediante interesses externos de um pequeno número de pessoas, empresas, políticos entre outros, impondo mudanças drásticas na vida de todos. Consequentemente, o que se verifica é o aprofundamento das desigualdades socioespaciais mediante lógicas dominantes, que definem quais territórios terão mais ou menos densidades técnicas-científicas-informacionais, definindo assim, quais serão mais fluidos, mais luminosos, ou seja, quais aqueles em que a globalização vai estar mais presente e dominante: o movimento da população, a distribuição da agricultura, da indústria e dos serviços, o arcabouço normativo, incluídas a legislação civil, fiscal e financeira (SANTOS; SILVEIRA, [2001] 2010).

Trilhando por este caminho, é notório que o mundo está longe de alcançar um equilíbrio, criando assim geografias da desigualdade (SOUZA, 1996), revelando a verdadeira face da globalização: a perversidade travestida de fabulações e sustentada por um espetáculo midiático que comunga da sua ideologia. Não obstante, é nítido que diante de crises profundas que acometem diversas nações, não consegue na prática concretizar seus discursos falaciosos de igualdade e liberdade econômica para todos, colocando em evidência a necessidade do Estado de resolver crises causadas não somente por problemas internos como externos, que muitas vezes são reflexos do que se passa no centro do sistema capitalista.

Assim, parece que o ano vigente vem demostrando que a globalização econômica e o seu sistema, são mais frágeis do que se pensava. Esse ano vem mostrar que a mão do Estado mais do que nunca passou a ser essencial, não somente para a população mais carente e marginalizada, que constantemente são escamoteadas pelos governantes submissos aos interesses internacionais, como também para o socorro de toda uma nação: seus sistemas econômico, de saúde, educacional, segurança etc. Ao mesmo tempo vem mostrar que a terceirização e privatização, tão requeridas e incentivadas nas últimas décadas por muitos governos liberais, não são a salvação, nem muito menos a saída das crises internas aos países. 
O ano de 2020 entra para história como aquele que fez o mundo tão movimentado 'parar'. Não por causa de tensões e conflitos armados que levariam ao estopim de uma guerra entre um país e outro por causa de riquezas naturais, bens materiais, ou para manter sua hegemonia frente aos demais, como já ocorreu em diversos momentos da história. Mas, uma guerra contra um inimigo não visto a olho nu e que vem causando estragos sem precedentes a maioria das nações, independente de desenvolvidas, emergentes ou subdesenvolvidas, a exemplo do eminente colapso nos sistemas de saúde - municipal, estadual e Federal - e da própria quebra ou diminuição nas mais diversas economias.

É uma guerra contra um vírus que se espalhou rapidamente por todos os continentes, o COVID19, que surgiu de forma avassaladora no continente asiático em fins do ano de 2019, num mercado de frutos do mar na cidade de Wuhan, uma das principais cidades da China, destacando-se na China Central nas questões políticas, econômicas, comércio, finanças etc., com uma indústria bastante forte que se destaca a nível mundial - fabricação de automóveis, ferro, aço e vários outros setores relacionados ao desenvolvimento tecnológico.

No que se refere aos coronavírus a Organização Mundial da Saúde/OMS (2020) nos mostra que:

Los coronavirus (CoV) son una amplia familia de virus que pueden causar diversas afecciones, desde el resfriado común hasta enfermedades más graves, como ocurre con el coronavirus causante del síndrome respiratorio de Oriente Medio (MERS-CoV) y el que ocasiona el síndrome respiratorio agudo severo (SRAS-CoV). Un nuevo coronavirus es una nueva cepa de coronavirus que no se había encontrado antes en el ser humano. Los coronavirus se pueden contagiar de los animales a las personas (transmisión zoonótica). De acuerdo con estudios exhaustivos al respecto, sabemos que el SRAS-CoV se transmitió de la civeta al ser humano y que se ha producido transmisión del MERS-CoV del dromedario al ser humano. Además, se sabe que hay otros coronavirus circulando entre animales, que todavía no han infectado al ser humano. Esas infecciones suelen cursar con fiebre y síntomas respiratorios (tos y disnea o dificultad para respirar). En los casos más graves, pueden causar neumonía, síndrome respiratorio agudo severo, insuficiencia renal e, incluso, la muerte.

Nesta 'guerra' que estamos vivendo precisamos nos armar de duas formas distintas e complementares. De um lado, pode-se dizer que a mais importante neste momento, é a urgência da proteção do Estado com políticas públicas eficientes: garantia e manutenção dos empregos e salários já existentes e que estão sendo ameaçados pelo empresariado; garantia de abastecimento de alimentos e medicamentos nos principais postos de comercialização; manutenção dos auxílios e criação de novos para quem não tem estabilidade e vive de trabalhos informais - os chamados microempreendedores individuais, que passaram a ser ovacionados pelos empresários e pela mídia como positivo, mas que em decorrência de não terem nenhuma estabilidade e nem garantias trabalhistas, se veem dependentes das ações do governo para protegê-los; a urgência de ampliação e/ou instalações de saúde adequadas e gratuitas para toda população que venha necessitar; entre outras medidas mais duras como forma de contenção e propagação desse inimigo invisível, o COVID-19. De outro lado, porém, não menos importante, o papel que cada cidadão e cidadã tem neste momento, o de se alto proteger, proteger sua família e, consequentemente, proteger toda a sociedade, tomando cuidados e medidas simples no dia a dia: lavar bem as mãos e com maior frequência; usar álcool em gel sempre que possível, principalmente, quando não dispor de água para uma maior higienização das mãos; manter distância segura das demais pessoas; e não sair de casa a não ser que seja realmente necessário. 
Em relação a esse segundo conjunto de medidas é sabido que nem todos têm condições e podem segui-las, principalmente, aquelas pessoas que vivem na periferia do capitalismo e que foram e são mantidas distantes do banquete da chamada globalização. É a maioria dos trabalhadores e trabalhadoras; são aqueles que vivem à margem da sociedade na periferia das grandes cidades ou nas mais remotas áreas das diversas regiões e países; os pobres e os miseráveis vistos e negados, tornados invisíveis por um capitalismo sedento por lucro e incentivador do consumo sem limite, apoiado pelo Estado e com o aval da grande mídia, a detentora do poder da informação no período atual. Juntam-se a esta as mídias alternativas que, ao mesmo tempo em que ajudam na difusão mais rápida das informações, fazendo-as chegar ao máximo de pessoas possíveis, contribuem na desinformação a partir das práticas de fake news espalhadas pelas diversas redes sociais, o mais novo elemento de difusão de informações nesse novo século.

Diante do constante ataque por parte desse inimigo contra a grande massa populacional, verifica-se uma mudança brusca no fluxo 'normal' da vida em sociedade, onde os 'invisíveis' começaram a aparecer e 'gritar o grito' dos silenciados. A classe trabalhadora - formais, informais, autônomos, pequenos e médios empreendedores - que agora se vê numa encruzilhada entre o emprego e a saúde, entre o morrer de fome ou morrer em decorrência do COVID-19, está necessitando como nunca da proteção do Estado para saírem vencedores nessa guerra. É o Estado, o poder público, e não a igreja, nem mesmo o capitalismo sedento por lucros, representado pelas grandes empresas e seu empresariado, que dará essa proteção tão necessária e urgente a classe trabalhadora que luta diariamente pela subsistência.

O Estado tem a obrigação de frear a evolução e propagação desse vírus. E para os países que ainda não estão afetados severamente pelo mesmo é o momento de contê-lo e evitar um caos não somente na saúde pública como também na particular, o que vem acontecendo em vários países no mundo, a exemplo de países europeus, como Itália e Espanha, e da própria potência norte-americana estadunidense que vem enfrentando uma onda gigantesca de contagiados e cifras alarmantes de mortos no país - decorrência do seu frágil sistema particular e do colapso causado pelo COVID-19.

Assim, uma medida que vem sendo considerada por órgãos específicos, como a OMS e por vários cientistas e especialistas na área da saúde e adotada por diversos países, como Itália, China, Espanha, França, Reino Unido, Portugal, mais recentemente os Estados Unidos e vários outros, é o isolamento e distanciamento social. Essa recomendação para frear a expansão e minimizar os estragos deixados pelo COVID-19 tem sido bastante eficaz, já que ainda não se tem nenhuma medicação ou vacina que possa imunizar a população, e não sendo esta doença apenas uma 'gripezinha', todos os cuidados devem seguir as recomendações, evitando necessitar de um leito de UTI (Unidade de Terapia Intensiva), visto que os leitos de UTIs não suportariam o contingente de infectados em função da difusão do vírus.

Assim, é importante seguir o isolamento e distanciamento de tudo e todos à risca, com exceção de algumas atividades tidas como essenciais: farmácias, supermercados e padarias. É o distanciamento e isolamento do trabalho, de aulas nas diversas instituições de ensino, de práticas esportivas e de vida cultural em aglomerações e fora de casa, de passeios, de convívio com os amigos, parentes entre tantos outros. Essas medidas parecem, por enquanto, serem as mais eficientes no controle e propagação do vírus, de modo a evitar a tragédia que vem acontecendo em alguns países, visto através dos números que não param de crescer. É sabido que os dados apresentados pelos países sofrem mudanças constantemente em virtude do rápido contágio e das complicações e resultados ocasionados pelo vírus.

Então, tendo como referência os dados disponíveis no site Johns Hopkins University \& Medicine para o dia 26 de abril de 2020 e apresentados na tabela 1, é possível ter um panorama das cifras de contágios e mortes no mundo e dos países mais contagiados por continente. Vale lembrar que o vírus não chegou nestes países de uma vez. Sua expansão foi se dando de acordo com a circulação de pessoas contaminadas, apresentando sintomas ou não. No Brasil por 
exemplo o primeiro caso foi diagnosticado no dia 26 de fevereiro, nos EUA data de 21 de janeiro e na China em Dezembro.

Tabela 1. Contágios e mortes: mundo e principais países por continente - 26 de Abril de 2020

\begin{tabular}{|c|c|c|c|c|c|c|}
\hline & \multirow{2}{*}{ Mundo } & \multicolumn{5}{|c|}{ Europa } \\
\hline & & Espanha & Itália & França & \multicolumn{2}{|c|}{ Alemanha } \\
\hline Contágios & 2.898 .082 & 223.759 & 195.351 & 161.644 & \multicolumn{2}{|c|}{156.513} \\
\hline Mortes & 203.025 & 22.902 & 26.384 & 22.614 & \multicolumn{2}{|c|}{5.877} \\
\hline Recuperados & 822.165 & 95.708 & 63.120 & 45.372 & \multicolumn{2}{|c|}{109.800} \\
\hline & \multicolumn{3}{|c|}{ Ásia } & \multicolumn{3}{|c|}{ América } \\
\hline & Iran & China & Índia & $E U A$ & Brasil & Canadá \\
\hline Contágios & 89.328 & 83.909 & 26.496 & 939.235 & 59.324 & 45.493 \\
\hline Mortes & 5.650 & 4.632 & 825 & 53.934 & 4.057 & 2.549 \\
\hline \multirow[t]{3}{*}{ Recuperados } & 68.193 & 78.175 & 5.939 & 105.819 & 29.160 & 16.013 \\
\hline & \multicolumn{3}{|c|}{ Oceania } & \multicolumn{3}{|c|}{ África } \\
\hline & Austrália & \multicolumn{2}{|c|}{ Nova Zelândia } & África do Sul & Egito & Marrocos \\
\hline Contágios & 6.694 & \multicolumn{2}{|c|}{1.470} & 4.361 & 4.319 & 3.897 \\
\hline Mortes & 79 & \multirow{2}{*}{\multicolumn{2}{|c|}{18}} & 86 & 307 & 159 \\
\hline Recuperados & 1.142 & & & 1.473 & 1.114 & 537 \\
\hline
\end{tabular}

Fonte: Johns Hopkins University \& Medicine. Acesso em: 26 de abril de 2020.

Os números vêm aumentando a cada dia, seja no que se refere aos contágios e mortes como também em relação aos recuperados. Alguns países já vêm diminuindo ou estabilizando os números de pessoas contagiadas e/ou mortas, enquanto outros que estão a pouco tempo lidando com o vírus mantém uma crescente em seus números. Os dados apresentados na Tabela 1 são bastantes elucidativos no que se refere a concentração dos infectados no mundo. Se de um lado têm-se países africanos com menos de 100 mortes, no caso da África do Sul com 86 e, no caso da Austrália na Oceania com 79 mortes, de outro lado têm-se países como a potência norteamericana estadunidense com 53.934 mortos o que representa $26,56 \%$ do total mundial de mortes por COVID-19, que é de 203.025 mortes, seguido por Itália (26.384), Espanha (22.902) e França (22.614), todos grandes países do continente europeu. Estes quatros países somam $61,97 \%$ do total de mortes a nível mundial.

No que concerne aos contagiados a concentração também está acima da linha do Equador (Figura 1), e novamente, com números alarmantes nos países já mencionados no parágrafo anterior. Estados Unidos e os quatro países com maiores números de contágios da Europa (Espanha, Itália, França e Alemanha) apresentam uma cifra de 1.676 .502 contagiados, números que representam $57,84 \%$ dos 2.898 .082 de contágios no mundo. Novamente chama atenção para os números do continente africano, onde os três com maior número de contágio (África do Sul, Egito e Marrocos) juntos corresponde a 12.577 infectados, quantitativo bem inferior se comparados com os países europeus apresentados e/ou mesmo com os Estados Unidos. Mesmo com números menores, os países africados apontados se sobressaem no continente como os mais afetados, podendo apontar, ao que nos parece, que por serem países de destaques em relação à economia e apresentar uma maior movimentação de pessoas a nível internacional, atrelado a outros fatores internos, contribuiu para essa maior cifra em relação aos demais.

Para além de contágios e mortes, é importante ressaltar a cifra de recuperados que chega a 822.165 no mundo. Desse total chama atenção a Alemanha que tem se destacando não somente no baixo número de mortes se comparado com os três países europeus mais afetados, como também no número de recuperados, 109.800 pessoas, o que equivale a $13,35 \%$ de todos os 
recuperados no mundo. $\mathrm{O}$ que se deve em grande parte, as medidas adotadas desde um primeiro momento para contenção e não propagação do vírus, como os testes em massa e criação de comitê voltado a doença antes do vírus chegar ao país (BBC BRASIL).

Figura 1. Casos acumulados confirmados de COVID19 no mundo. Acesso em: 26 de abril de 2020

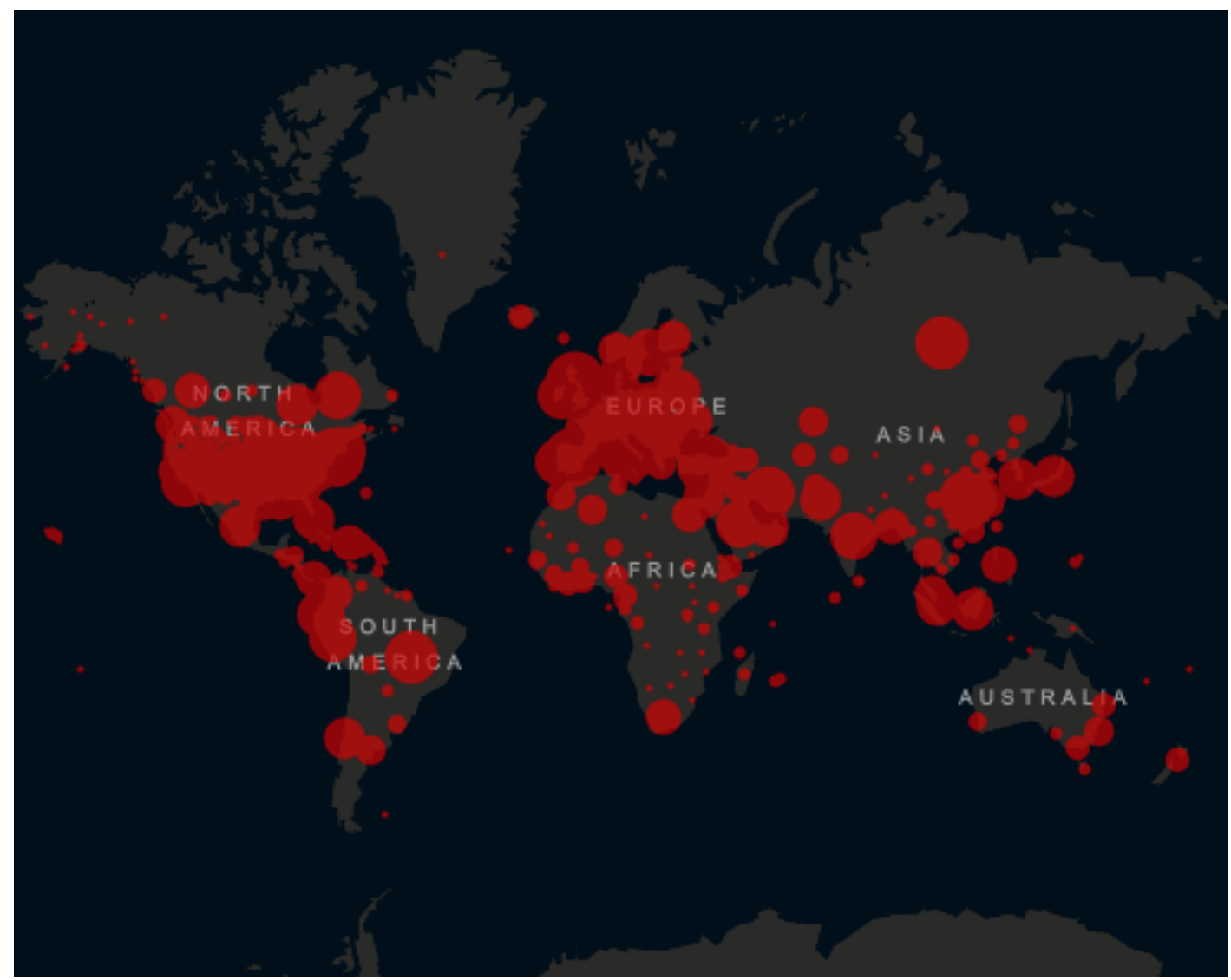

Fonte: Johns Hopkins University \& Medicine. Acesso em: 26 abril de 2020.

É interessante notar que os países com os maiores números de infectados e mortes são justamente aqueles, de um conjunto maior de países desenvolvidos, onde se têm os maiores fluxos do mundo presente: finanças, transportes (aéreos, marítimos, terrestre) e informações. É justamente onde estão presentes as maiores bolsas econômicas do mundo (a exemplo das Bolsas de Valores de New York (NYSE), NASDAQ, Shanghai e Euronext) e os representantes mais poderosos do atual sistema capitalista, inserindo a socialista China, do chamado mundo globalizado (Figura 2). Isso nos mostra, e parece verídico, que o COVID-19 ganhou impulso e pegou 'carona' neste fenômeno da globalização, deslocando-se de um país a outro de forma muito rápida, principalmente, através dos fluxos aéreos, ou como afirma Castilho (2020, p. 2):

É tributário da modernização contemporânea e, por isso, carrega figurativamente o DNA da globalização. É por isso que em seu gene, há uma perversidade que antecede sua própria natureza epidêmica. Compreendê-la demanda considerar especialmente o tipo de sociedade que gestou o vírus, mas que se revela profundamente incapaz de enfrentá-lo. 
Figura 2. Maiores bolsas de valores por região no mundo. Acesso em: 26 de abril de 2020

\section{Maiores Bolsas de Valores por região ${ }^{1}$}

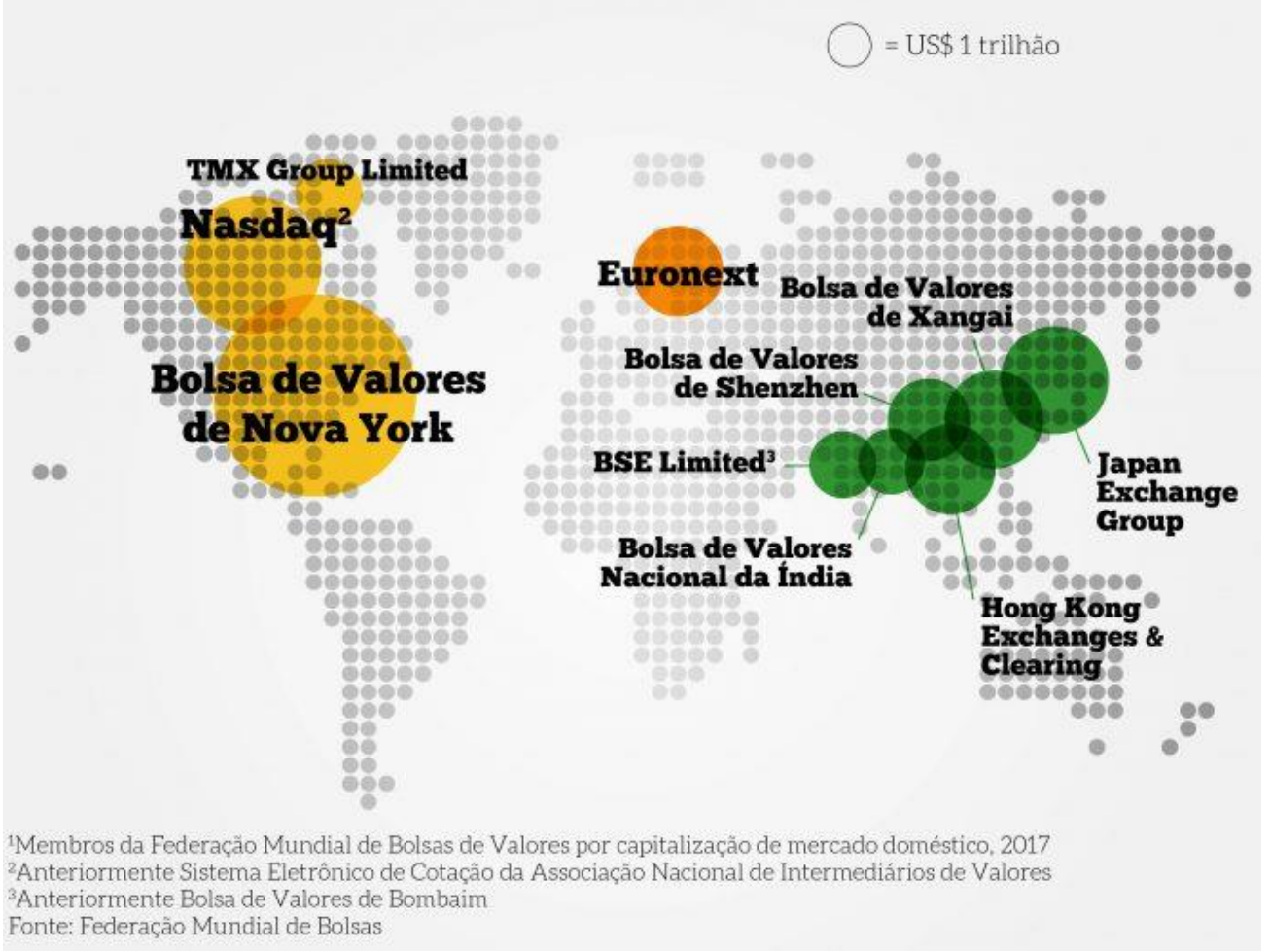

Fonte: ShareAmerica. Acesso em: 26 de abril de 2020

\section{DESIGUALDADES REGIONAIS E O COVID-19 NO BRASIL}

A desigualdade regional da realidade brasileira é resultado dos longos cinco séculos de história, começando com a invasão e ocupação do território pelos europeus, com maior intensidade pelos portugueses. Devastaram a mata nativa, dizimaram, escravizaram e expulsaram os índios nativos destas terras e usurparam tudo que puderam, e enquanto puderam, das riquezas nacionais. Ao longo destes séculos as regiões foram sendo (re)definidas e exploradas mediante os interesses dos atores hegemônicos em cada época e das materialidades que iam sendo impostas ao território para que dele pudessem ser extraído o máximo de riqueza possível.

Para o entendimento da realidade brasileira, com enormes desigualdades espalhadas pelo território, podemos pensar o Brasil a partir da existência de quatro Brasis, conforme Santos e Silveira ([2001] 2010, p. 268), baseando-se, "simultaneamente, numa atualidade marcada pela difusão do meio técnico-científico-informacional e nas heranças do passado", quais seriam: Região Concentrada (Sudeste e Sul), o Brasil do Nordeste, o Centro-Oeste e a Amazônia.

Pensando o Brasil a partir dessa divisão, veremos que a referida Região Concentrada é justamente onde estão as maiores densidades técnicas, científicas e informacionais, as maiores concentrações financeiras, os maiores fluxos, as maiores concentrações populacionais, ao tempo em que concentra muitas das desigualdades do país. As desigualdades aí são mais visíveis e mais chocantes, basta olhar para a realidade dos luxuosos prédios e mansões do Morumbi e o 'mar' de residências simples da segunda maior favela de São Paulo, Paraisópolis, onde apesar da falta de infraestrutura, segurança e serviços de saúde e educação, o seu povo mantem-se de cabeça erguida. 
Essa realidade não é exclusiva do estado de São Paulo. O Rio de Janeiro apresenta suas belíssimas praias e orla que vai do Leblon a Copacabana, o imponente Cristo Redentor e o Pão de Açúcar, mas ao mesmo tempo ofusca a realidade das favelas que necessitam de ações do poder público, sendo estas uma realidade que surgiu no Brasil em fins do século XIX, como resultado das transformações socioespaciais da época. A cidade do Recife em Pernambuco com toda sua riquíssima história também apresenta suas desigualdades, desde as casas de palafitas nos mangues do Capiberibe e sua gente, tantas vezes apresentadas nos escritos de Josué de Castro, até aos moradores em condições de rua que vagam pelo Centro Histórico e ou mesmo pela orla de Boa Viagem. O que dizer de Brasília, onde concentra a política brasileira com toda uma cidade planejada para receber a capital do Brasil e a presença de uma das maiores favelas do país, a Sol Nascente em Ceilândia? As desigualdades são enormes e presentes em todas as regiões, e muitas vezes estão aí a tanto tempo que parecem esquecidas pelos governantes e comum aos olhos.

Destarte, não podemos deixar de pensar e refletir sobre a situação em que milhares de pessoas, espalhadas pelas cinco regiões do Brasil (divisão político-administrativa - IBGE), se encontram neste momento em que o mundo vive uma pandemia. Assim, como vem acontecendo a nível mundial em relação a propagação do vírus, a realidade nacional vai seguindo a mesma escalada, com algumas exceções. Analisando os contágios e mortes no país, verificaremos que a grande massa está presente na Região Concentrada e em pontos específicos de outros estados e regiões brasileiras, e que vem se espalhando numa velocidade muito rápida. Segundo dados do Ministério da Saúde do Brasil para o dia 25/4/2020, o país apresentou 58.509 mil casos confirmados e 4.016 mil óbitos (tabela 2). Baseando-se nesses dados apresentamos a tabela 2 que mostra como se encontram os estados e regiões.

Os dados - em constante crescimento - mostram que a região Sudeste e Sul juntas contabilizam 33.353 mil casos de contágios confirmados o que representa $57 \%$ dos casos do país. Segue o Nordeste, Norte e Centro-Oeste com, respectivamente, $27,84 \%, 11,75 \%$ e 3,38\% do total de confirmados. Já em número de óbitos o estado de São Paulo é o mais atingido, seguido do Rio de Janeiro, o que faz do Sudeste a região mais acometida pelo vírus em quantidade de casos. Mas, em nível estadual seguem esses dois, em maior número de óbitos, os estados de Pernambuco, Ceará e Amazonas. Já a região Centro-Oeste e Sul aparecem como as menos atingidas.

Como os números de casos de contágios e mortes mudam constantemente, apresenta-se na sequência (Figura 3), de acordo com as cifras de mortes no país, tendo como data de referência o dia 03 maio de 2020 e um total para o Brasil de 6.761 mortes, um gráfico com o número de mortes por 100 mil habitantes (segundo a fonte foram levadas em consideração as cidades com mais de 30 casos confirmados), mostrando que das 20 primeiras cidades oito são do estado do Amazonas, quatro de Pernambuco, duas do Ceará, Pará e São Paulo, e uma no Maranhã e Paraíba. Com exceção de São Paulo, todas as demais estão localizadas no Norte e Nordeste do país. Pode-se dizer que são cidades localizadas onde não dispõem de condições mínimas de infraestruturas e higiene, a exemplo de saneamento básico, como apontado no artigo "Covid-19, desigualdade social e tragédia no Brasil", da professora da USP Larissa Bombardi no Le Monde Diplomatique Brasil.

Tabela 2. Casos e óbitos: Brasil, regiões e estados com maior número de casos

\begin{tabular}{l|c|c}
\hline \multicolumn{1}{c|}{ Regiões/Estados } & Casos Confirmados & Óbitos \\
\hline Norte & $\mathbf{6 . 8 8 0}$ & $\mathbf{4 1 5}$ \\
\hline Amazonas & 3.635 & 287 \\
Pará & 1.579 & 86
\end{tabular}




\begin{tabular}{l|c|c} 
Amapá & 685 & 19 \\
\hline Nordeste & $\mathbf{1 6 . 2 9 3}$ & $\mathbf{1 . 0 0 2}$ \\
\hline Ceará & 5.421 & 310 \\
Pernambuco & 4.507 & 381 \\
Bahia & 2081 & 70 \\
\hline Centro-Oeste & $\mathbf{1 . 9 8 3}$ & $\mathbf{6 7}$ \\
\hline Distrito Federal & 1.013 & 26 \\
Goiás & 506 & 25 \\
Mato Grosso & 247 & 9 \\
\hline Sudeste & $\mathbf{2 9 . 9 0 8}$ & $\mathbf{2 . 3 8 7}$ \\
\hline São Paulo & 20.004 & 1.667 \\
Rio de Janeiro & 6.828 & 615 \\
Espírito Santo & 1.595 & 47 \\
\hline Sul & $\mathbf{3 . 4 4 5}$ & $\mathbf{1 4 5}$ \\
\hline Santa Catarina & 1.209 & 42 \\
Paraná & 1.140 & 69 \\
Rio Grande do Sul & 1.096 & 34 \\
\hline Total Brasil & $\mathbf{5 8 . 5 0 9}$ & $\mathbf{4 . 0 1 6}$ \\
\hline
\end{tabular}

Fonte: Ministério da Saúde do Brasil. Acesso em: 26 de abril de 2020

Figura 3. Cidades no Brasil com maior taxa de mortalidade de COVID-19

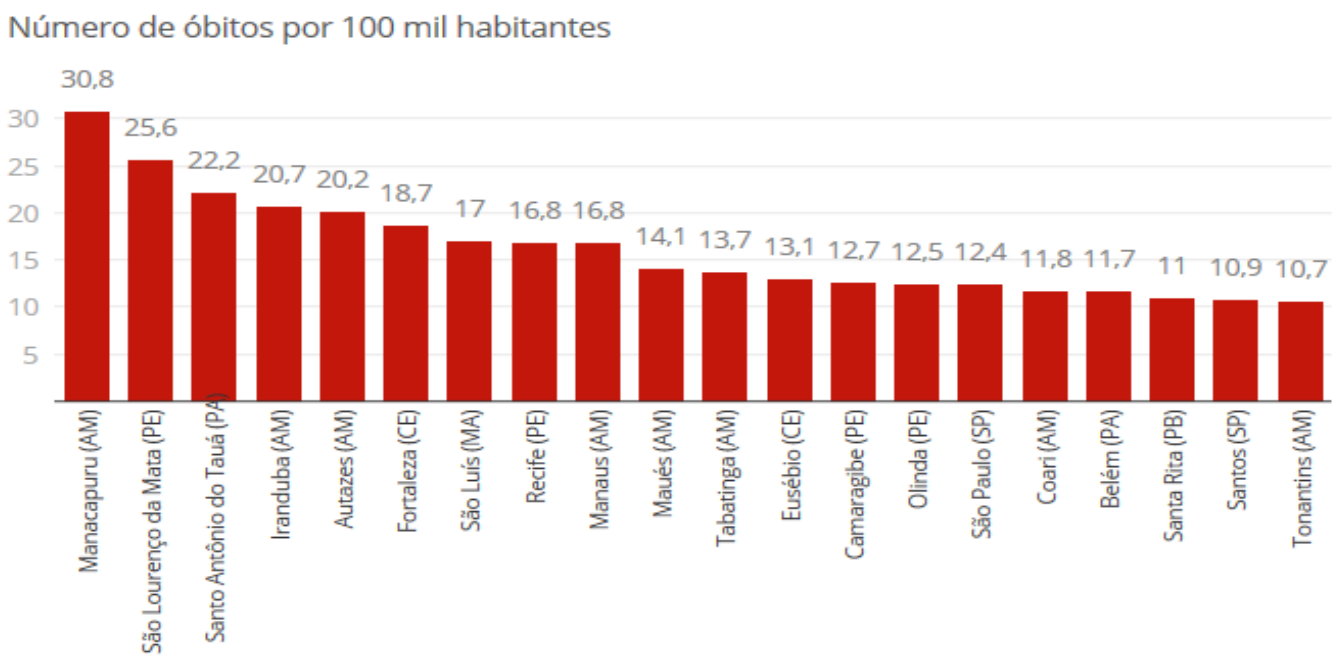

Fonte: Portal de notícias (https://g1.globo.com/). Acesso em: 04 de maio de 2020

Esses dados, se comparados com mapas onde têm-se maiores concentrações, densidades e fluxos a nível nacional, revelam a presença mais ou menos intensa do contágio de COVID-19 no Brasil (Figura 4), atrelado a maior ou menor presença de infraestruturas adequadas a prevenção, tratamentos e contenção do vírus. Além do posicionamento político estadual e municipal. 
Figura 4. Tráfego aéreo regional e nacional - companhias vigentes na ANAC em 2016.

Em ordem descrecente por participação do mercado nacional (ANAC,2016)

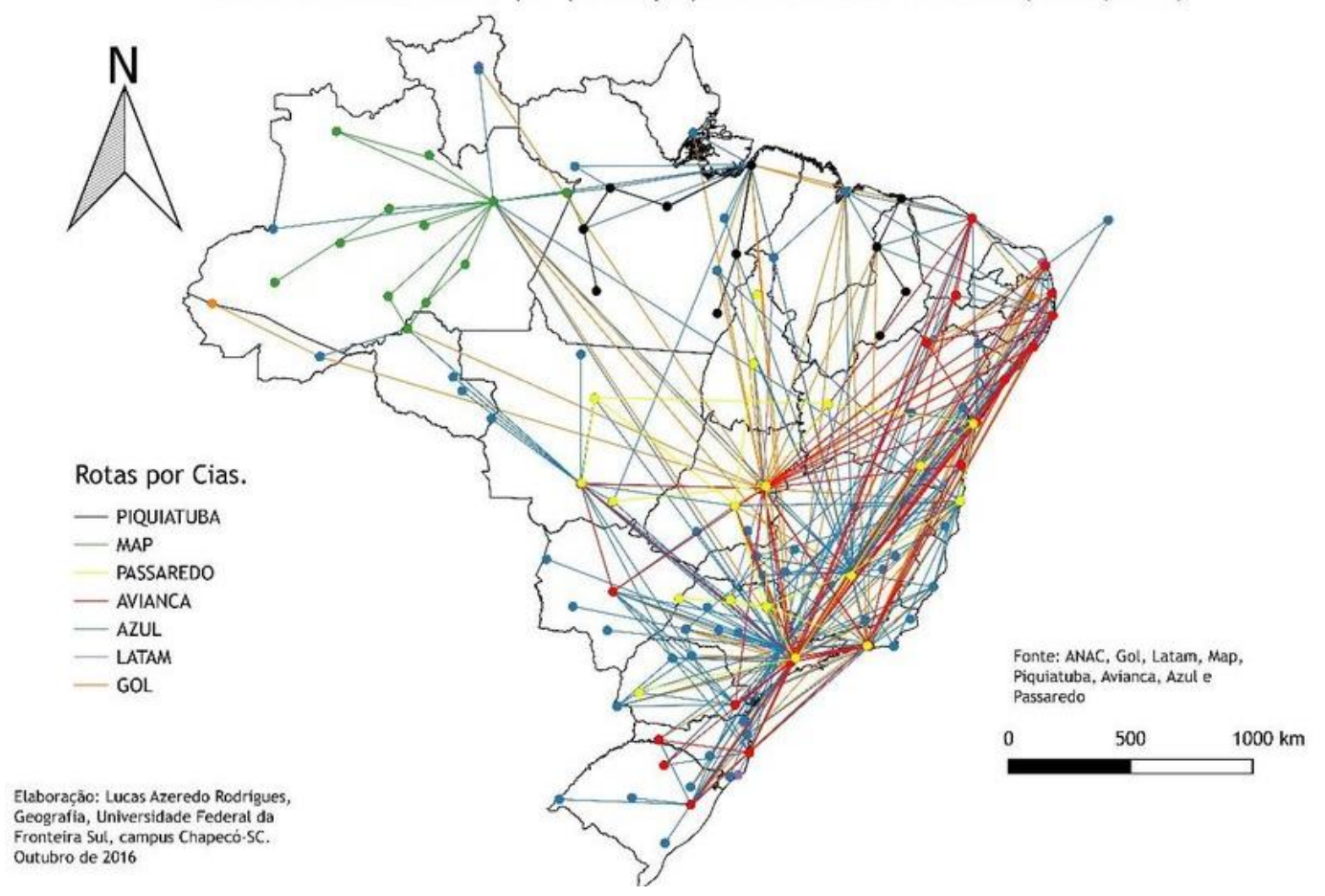

Fonte: Researchgate. Acesso em: 26 de abril de 2020

Assim, diante das diversas realidades e particularidades existentes em cada região e estado brasileiro, é urgente a necessidade da presença do Estado e a aplicação correta de políticas públicas no enfrentamento ao COVID-19, bem como seguir todas as recomendações da OMS, dos demais órgãos (Secretarias Municipais e Estaduais, Ministérios de Saúde etc.) e profissionais da área da saúde que estão à frente dessa guerra, e evitar seguir recomendações que estejam voltadas apenas para a manutenção da economia e deixando de lado o bem-estar e saúde da população. Neste caso em específico, chamamos a atenção para a realidade brasileira, onde o Presidente Jair Messias Bolsonaro vem se opondo a tudo e todos que vão na contramão do movimento e circulação da população, comércio e, consequentemente, da economia e do mercado, a quem o mesmo serve submissamente. Inclusive, levando a demissão do Ministro da Saúde, Luiz Henrique Mandetta, no último dia 16 de abril, e a nomeação de Nelson Teich que está, segundo ele, alinhado totalmente ao seu governo. Ao tempo em que Bolsonaro vem se posicionando contra governadores que estão seguindo as devidas recomendações, contra a mídia que diariamente mostra seu posicionamento, incitando e participando de manifestações contra o isolamento social, provocando aglomerações ao deixar a quarentena e indo ao encontro dos seus seguidores, cumprimentando-os e mantendo todo tipo de contato direto com os mesmos, o que vêm a ser propício para propagação do vírus. Sendo este posicionamento criticado e não recomendado no combate a esta pandemia. Já que destoa do isolamento e distanciamento recomendados pela OMS.

\section{ALGUMAS REFLEXÕES FINAIS}

Diante do exposto nestas páginas podemos perceber que o mundo vem enfrentando uma 
pandemia, entendida aqui como uma guerra, causada por um vírus, o inimigo invisível COVID19, que deixou o mundo em alerta e em constante luta no seu enfrentamento. Assim, o mundo globalizado, das grandes economias capitalistas e dos Estados nacionais, bem como da classe trabalhadora, dos miseráveis e invisíveis do período atual, estão enfrentando a mesma guerra, por mais que uns tenham condições e acesso a mais que outros.

Nesta guerra os soldados não são os mesmos de sempre, aqueles que se alistam no exército e são convocados quando se tem a necessidade de defender a soberania nacional. Nesta guerra todos estão desarmados dos tradicionais armamentos bélicos que, recebem vultuosos investimentos por parte dos países em detrimento de serviços públicos básicos como educação e saúde. Nesta guerra também não é admissível aceitar governantes que coloquem suas 'tropas' desarmadas nas mãos do inimigo, pondo em risco a vida da população e de sua nação.

A situação em que vive a maioria da população mundial frente a velocidade e letalidade com que o vírus se espraia é algo que nos assusta, em virtude das enormes desigualdades existentes em todos os países, ao mesmo tempo, em que essa situação nos traz à tona a importância que é ter a soberania nacional e o Estado no enfrentamento desta pandemia, buscando medidas e tomando decisões urgentes voltadas a toda população. No caso do Brasil, de extensão territorial continental, se faz urgente uma maior distribuição de renda e políticas públicas adequadas de acordo com a realidade de cada região, sem as quais dificulta a possibilidade de isolamento, não somente voltadas a esta guerra, mas para o bem-estar social e da vida de todos os cidadãos e cidadãs brasileiras: fortalecimento da educação em todos os níveis, manutenção e investimentos voltados à pesquisa em todas as áreas, bem como à saúde pública, em especial para o Sistema Único de Saúde/SUS (sistema público e gratuito), valorização dos(as) trabalhadores(as) e seus respectivos salários, entre outras medidas que devem ser implantadas pelo poder público.

Portanto, nessa guerra todos nós somos os 'soldados' e teremos pela frente uma longa batalha. É através da quarentena com isolamento social e devidos cuidados pessoais e coletivos que muitos países estão reduzindo a curva de contágio e de mortes a cada dia. É com a redução drástica do movimento, sugeridas em todas as instâncias, e que sempre foi incentivado pelos principais atores da globalização, que venceremos essa guerra e sairemos vivos para seguirmos lutando, ou como aponta Jesus Neto (2020) em artigo publicado em Outras Palavras: "ou desaceleramos ou morremos todos."

\section{AGRADECIMENTOS}

À Fundação de Amparo à Pesquisa do Estado de São Paulo (FAPESP), ao Grupo de Trabalho Geografia e COVID-19 do Departamento de Geografia da USP. E a Dhiego Medeiros, Lúcia Lirbório e Ricardo Leão, pelas sugestões e leitura final do texto.

\section{REFERÊNCIAS}

BAUMAN, Z. Globalização: as consequências humanas. Rio de Janeiro: Zahar, 1999.

BOMBARDI, L. COVID-19, desigualdade social e tragédia no Brasil. In: Le Monde Diplomatique Brasil. Acesso em 04/5/2020. < https://diplomatique.org.br/covid-19-desigualdade-social-e-tragedia-no-brasil/>

CASTILHO, D. Um vírus com DNA da globalização: o espectro da perversidade. In: Espaço e Economia: Revista Brasileira de Geografia Econômica. Rio de Janeiro, ano IX, nº 17, pp. 1-7, 2020.

CASTRO, J. de. Geopolítica da fome: ensaio sobre os problemas de alimentação e de população. São Paulo: Brasiliense, $2^{\circ}$ v. 8 ed. [1951] 1968. 
JESUS NETO, A. G. de. Ou desaceleramos ou morremos todos. In: Outras Palavras: Jornalismo de Profundidade e Pós-Capitalismo. Acesso em 27/03/2020. <https://outraspalavras.net/crisecivilizatoria/ou-desaceleramos-ou-morremos-todos/>

MAMIGONIAN, A. Tecnologia e desenvolvimento desigual no centro do sistema capitalista. In: Revista de Ciências Humanas. Santa Catarina, n. 2, pp. 38-48, 1982.

Marxismo e globalização: as origens da internacionalização. In. Estudos de Geografia Econômica e de Pensamento Geográfico. Livre Docência apresentada na Faculdade de Filosofia, Letras e Ciências Humanas - FFLCH/USP. São Paulo, vol. 1, pp. 139-146, 2004.

MARX, K. Contribuição à crítica da economia política. São Paulo: Martins Fontes, 3º ed., [1859] 2003.

SANTOS, M. O retorno do território. In: SILVEIRA, M. L. [et al] (Org.). Território, Globalização e Fragmentação. São Paulo: Hucitec, 3 ed., pp. 15-20 1996.

Técnica, espaço e tempo: globalização e meio técnico-científico-informacional. São Paulo: Editora da Universidade de São Paulo/EDUSP, 5a ed., [1994] 2008. 174p. (Coleção Milton Santos; 11).

A natureza do espaço: técnica e tempo, razão e emoção. São Paulo: Editora da Universidade de São Paulo/EDUSP, [1996] 2008. 384p.

Por uma outra Globalização - do pensamento único a consciência universal. 16 ${ }^{\mathrm{a}}$ ed. Rio de Janeiro: Record, [2000] 2008.

SCHIFFER, S. R. A globalização da economia e o território nacional - indagações prospectivas. In: SILVEIRA, M. L. [et al] (Org.). Território, Globalização e Fragmentação. São Paulo: Hucitec, 3 ed., pp. $116-124,1996$

SILVEIRA, M. L. Uma situação geográfica: do método a metodologia. Revista Território. Ano IV, número 6, jan./jun. pp. 21-28, 1999.

SOUZA, M. A. A. de. Geografias das desigualdades: globalização e fragmentação. In: SILVEIRA, M. L. [et al] (Org.). Território, Globalização e Fragmentação. São Paulo: Hucitec, 3 ed., pp. 21-28, 1996.

Sites Acessados:

https://coronavirus.jhu.edu/map.html. Acessado em 26/4/2020

https://www.who.int/es/emergencies/diseases/novel-coronavirus-2019. Acessado em 12/4/2020

https://share.america.gov/pt-br/uma-analise-da-maior-bolsa-de-valores-do-mundo/. Acessado em $26 / 4 / 2020$

https://covid.saude.gov.br/. Acessado em 26/4/2020

https://www.researchgate.net/figure/Figura-3-Mapa-do-trafego-aereo-no-Brasil-em-2016-Org-Autor2016_fig2_333632787. Acessado em 26/4/2020. https://www.bbc.com/portuguese/internacional52006158. Acessado em 04/05/2020

https://g1.globo.com/bemestar/coronavirus/noticia/2020/05/03/casos-de-coronavirus-e-numero-demortes-no-brasil-em-3-de-maio.ghtml. Acessado em 04/5/2020. 